\title{
PLASMA-ELECTROLYTIC NITRIDING OF 0.3Cr-1Mn-1Si-Fe CONSTRUCTION STEEL
}

\author{
${ }^{1}$ Layla ZHUREROVA, ${ }^{2}$ Bauyrzhan RAKHADILOV, ${ }^{1}$ Yerkezhan TABIEVA \\ ${ }^{1}$ D. Serikbayev East-Kazakh State Technical University, Ust-Kamenogorsk, Kazakhstan, \\ leila uka@mail.ru, erkezhan.tabieva@mail.ru \\ ${ }^{2}$ S. Amanzholov East Kazakh State University, Ust-Kamenogorsk, Kazakhstan, bor1988@mail.ru
}

https://doi.org/10.37904/metal.2019.910

\begin{abstract}
This work is devoted to experimental research of the influence of technological parameters of plasmaelectrolytic modification on the structural-phase condition, also changes in the mechanical and tribological properties of the surface layers of structural steel $0.3 \mathrm{Cr}-1 \mathrm{Mn}-1 \mathrm{Si}-\mathrm{Fe}$ after plasma-electrolytic processing. Metallographic analysis methods using «NEOPHOT-21» and «AXIOPHOT-2» optical microscopes, X-ray diffraction analysis on X'PertPRO and XRD-6000 diffractometers in monochromatic CuK ${ }_{\alpha}$ radiation, as well as elemental analysis on scanning electron microscopes FEIXL-30-FEG and JSM6390-LV, mechanical testing for microhardness on the installation PMT-1M, methods for measuring wear resistance according to the "balldisk" scheme and corrosion resistance obtained the following results: microstructure of steel $0.3 \mathrm{Cr}-1 \mathrm{Mn}-1 \mathrm{Si}$ $\mathrm{Fe}$ after nitriding in electrolyte plasma according to mode 1 consist from a-phase and iron nitride (FeN); and mode 2: at a temperature of $700-750^{\circ} \mathrm{C}$ with a treatment time of 3-7 minutes, a layer consisting of $\alpha-\mathrm{Fe}$, oxides $\left(\mathrm{Fe}_{2} \mathrm{O}, \mathrm{FeO}\right)$ and iron $\mathrm{FeN}$ nitride and $\varepsilon$ - is formed in the electrolyte, which is characterized by ammonium chloride $\left(\mathrm{NH}_{4} \mathrm{Cl}\right)$ content phases (solid solution based on iron nitride $\mathrm{Fe}_{3} \mathrm{~N}$ ) with a thickness of $30 \mu \mathrm{m}$, which is highly resistant to corrosion. It was determined that after plasma electrolytic nitriding at a temperature of $850{ }^{\circ} \mathrm{C}$ for 7 minutes, the wear rate as compared to the initial state of the $0.3 \mathrm{Cr}-1 \mathrm{Mn}-1 \mathrm{Si}-\mathrm{Fe}$ steel samples decreased 4.3 times.
\end{abstract}

Keywords: Plasma electrolytic nitriding, structural steel, structural and phase condition, wear resistance

\section{INTRODUCTION}

It is known [1-2] that the chemical heat treatment of metals and alloys in electrolyte plasma attracts wide attention of researchers with new technological capabilities. The modes for carrying out processes of gas and vacuum carburizing, nitriding, carbonitriding, boronizing and pulsed hardening are established by researches of the USA, Great Britain, China, Japan, Iran, Russia, Ukraine, Belarus and other countries. All cathodic processes of modification are accompanied by intense electrical discharges that contribute to the formation of a steady steam-gas shell (SGS) around the processed surface. However, the processes of traditional thermal or chemical-thermal treatment with duration of 10-30 hours are accompanied by the inevitable formation of an oxide layer. This layer significantly affects to the processes of dissolution and diffusion saturation of the processed surface. The existence of this layer determines all the specifics of the heating of the electrode in aqueous electrolytes in the process of electrolytic-plasma treatment (EPT) [3-5]. Therefore, one of the main tasks in the field of chemical heat treatment is the intensification of technological parameters (processing time, temperature and electrolyte composition), which affect the performance of the process and improve the performance characteristics of the workpiece. Thus, one of the most perspective and resource-saving technologies of hardening machine parts, in our opinion, is EPT technology [6]. Studying of change of a structural-phase state and increase of wear resistance of steel $0.3 \mathrm{Cr}-1 \mathrm{Mn}-1 \mathrm{Si}-\mathrm{Fe}$ after nitriding in the electrolyte plasma is of scientific and practical interest for the development of the technology of hardening and processing of products to increase practically important operational properties.

Due to the above, the purpose of this work is research of changes of morphology of a microstructure and Mehano - tribological properties of the modified steel 30HGSA at electrolytic and plasma nitriding. 
For achievement of a goal, as material of a research were used billet samples of $0.3 \mathrm{Cr}-1 \mathrm{Mn}-1 \mathrm{Si}-\mathrm{Fe}$ steel in the form of parallelepipeds $(30 \mathrm{~mm} \times 30 \mathrm{~mm} \times 8 \mathrm{~mm}$ ) in a condition of delivery, and in the processed states under different electrolytic-plasma nitriding conditions. The chemical composition of steel: $0.28-0.35 \%$ C; 0.8$1.1 \% \mathrm{Cr} ; 0.8-1.1 \% \mathrm{Mn} ; 0.9-1 \% \mathrm{Si} ; 0.025 \% \mathrm{P} ; 0.025 \% \mathrm{~S}$, the rest of Fe according to GOST 4543-71.

Before electrolytic-plasma treatment, the samples were subjected to mechanical grinding and polishing on a polishing wheel using diamond pastes, and were also subjected to chemical selective etching in a $3 \%$ solution of nitric acid in ethyl alcohol to reveal the microstructure of the steel surface.

Plasma-electrolytic modification of steel $0.3 \mathrm{Cr}-1 \mathrm{Mn}-1 \mathrm{Si}-\mathrm{Fe}$ samples were carried out at the facility, which was developed and manufactured at the Technical Physics Department of D. Serikbayev EKSTU employees of LLP "TechnoAnalit" and SRI "Nanotechnology and New Materials" [7]. Electrolyte-plasma nitriding in the cathode mode was carried out in an aqueous solution of active electrolytes. The EPT process includes processing in an arc discharge created between a liquid electrode and the surface of the cathode, with endurance at a temperature of $700-850^{\circ} \mathrm{C}$ and lasting 5-7 min.

Table 1 Technological parameters of the EPT

\begin{tabular}{|c|c|c|c|c|c|}
\hline \multirow{7}{*}{ 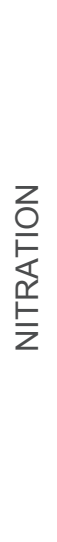 } & $\begin{array}{l}\text { Steel sample } \\
0.3 \mathrm{Cr}-1 \mathrm{Mn}-1 \mathrm{Si}-\mathrm{Fe}\end{array}$ & Temperature, $\mathrm{t},{ }^{\circ} \mathrm{C}$ & Time, $t$, min & Voltage, U, B & Current, I, A \\
\hline & \multirow{2}{*}{ Mode 1} & \multirow{2}{*}{$750-850$} & 5 & $320 / 180$ & \multirow{2}{*}{$25-30$} \\
\hline & & & 7 & $320 / 160$ & \\
\hline & \multicolumn{5}{|c|}{ The composition of the electrolyte: an aqueous solution of $15 \%$ soda ash $\left(\mathrm{Na}_{2} \mathrm{CO}_{3}\right)$ and $25 \%$ urea $\left(\left(\mathrm{NH}_{2}\right)_{2} \mathrm{CO}\right)$} \\
\hline & \multirow{2}{*}{ Mode 2} & \multirow{2}{*}{$700-750$} & 5 & $320 / 180$ & \multirow{2}{*}{$25-30$} \\
\hline & & & 7 & $320 / 160$ & \\
\hline & \multicolumn{5}{|c|}{$\begin{array}{l}\text { The electrolyte composition: an aqueous solution of } 10 \% \text { ammonium chloride }\left(\mathrm{NH}_{4} \mathrm{Cl}\right) \text { and } 10 \% \text { soda ash } \\
\qquad\left(\mathrm{Na}_{2} \mathrm{CO}_{3}\right) \text { and } 15 \% \text { urea }\left(\left(\mathrm{NH}_{2}\right)_{2} \mathrm{CO}\right)\end{array}$} \\
\hline
\end{tabular}

Researches of morphology of $0.3 \mathrm{Cr}-1 \mathrm{Mn}-1 \mathrm{Si}-\mathrm{Fe}$ steel samples was carried out at the Scientific Research Institute of Nanotechnologies and new materials at D. Serikbayev EKSTU by optical microscopy at "ALTAMIMET". The research of phase composition and structural parameters of the samples was carried out on a Shimadzu XRD-6000 diffractometer using CuKa radiation. The analysis of phase composition, size of coherent scattering regions, internal elastic stresses $(\Delta d / d)$ was performed with use of PCPDFWIN and PDF4 + databases, as well as POWDER CELL 2.4 full-profile analysis programs (TSU Collective Use Material Research Center, Tomsk, Russia). The microhardness of the surface layers of the of $0.3 \mathrm{Cr}-1 \mathrm{Mn}-1 \mathrm{Si}-\mathrm{Fe}$ steel samples before and after nitriding was measured by pressing the diamond pyramid on a PMT-3M instrument with a load of $1 \mathrm{~N}$ according to GOST 9450-76. The research of wear resistance was performed on a hightemperature TNT CSM Instruments tribometer, the recommended conditions for tribological tests according to ASTM G99 "Standard Test Testing with a Pin-on-Disk Apparatus" standard. The friction coefficient for steel samples of $0.3 \mathrm{Cr}-1 \mathrm{Mn}-1 \mathrm{Si}-\mathrm{Fe}$ is calculated from amount of the material removed during the test due to friction and wear.

At a morphology research of structure of the near-surface layers of the of $0.3 \mathrm{Cr}-1 \mathrm{Mn}-1 \mathrm{Si}-\mathrm{Fe}$ steel samples after nitriding in the electrolyte plasma in Figure 1a, at different values of the processing time, were found significant phase and structural changes. The microstructure of the surface layer of steel of $0.3 \mathrm{Cr}-1 \mathrm{Mn}-1 \mathrm{Si}-\mathrm{Fe}$ in the state of delivery consists of grains of ferrite and perlite, which are located from each other in a random way. Approximately $60 \%$ of the main volume of the surface of the investigated steel is occupied by perlite grains. The average grain size of perlite is about $12.7 \mu \mathrm{m}$, and the average grain size of ferrite is somewhat smaller and amounted to $9.4 \mu \mathrm{m}$. 

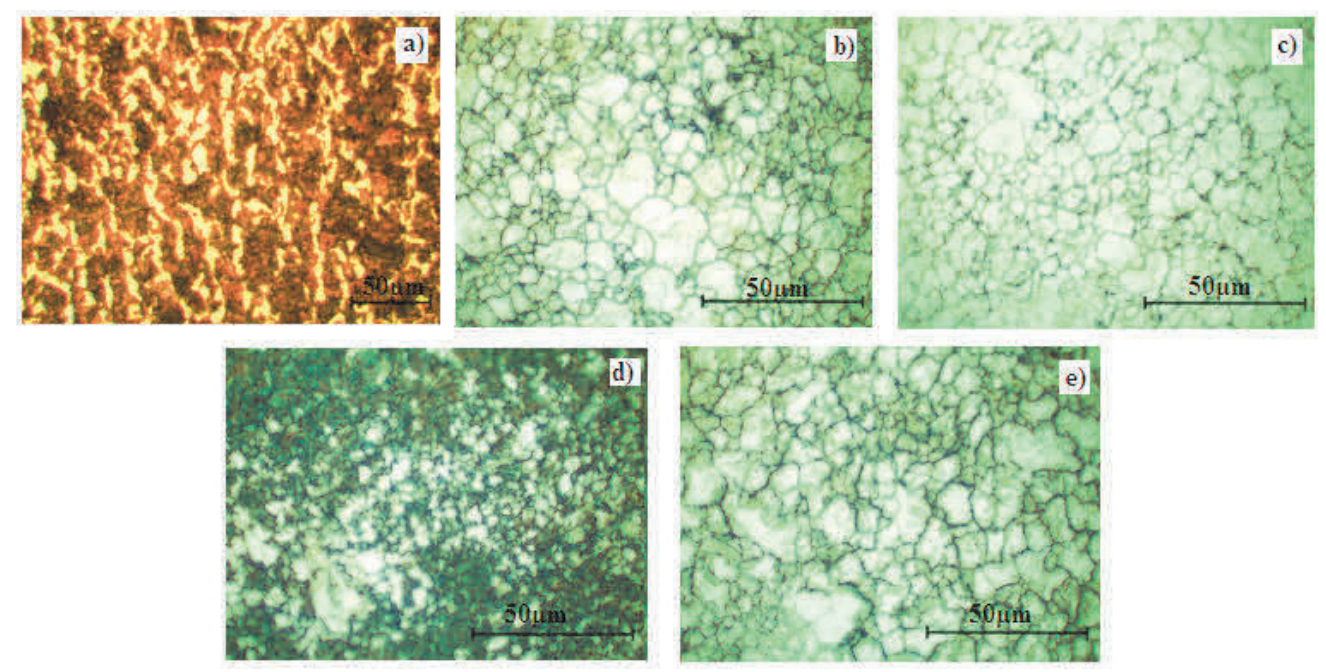

a) Initial condition.

Mode 1 - under a temperature of $750-850^{\circ} \mathrm{C}$ : b) 5 min., c) 7 min.

Mode 2 - under a temperature of $700-750^{\circ} \mathrm{C}$ : d) $5 \mathrm{~min}$., e) $7 \mathrm{~min}$.

Figure 1 The microstructure of steel $0.3 \mathrm{Cr}-1 \mathrm{Mn}-1 \mathrm{Si}-\mathrm{Fe}$ before and after modification by nitriding

As a result of the analysis of the fragments of the microstructure in Figures 1 (b-e) obtained by method of optical microscopy, it is established that after nitriding samples of $0.3 \mathrm{Cr}-1 \mathrm{Mn}-1 \mathrm{Si}-\mathrm{Fe}$ steel in the plasma of electrolyte there are changes of morphology of a near-surface layer of $0.3 \mathrm{Cr}-1 \mathrm{Mn}-1 \mathrm{Si}-\mathrm{Fe}$ steel. When samples are nitriding in electrolyte plasma, ferrite is enriched by atomic nitrogen, which promotes the growth of nitride particles in the near-surface modified layer. The microstructure of the near-surface layer of $0.3 \mathrm{Cr}-1 \mathrm{Mn}-1 \mathrm{Si}-\mathrm{Fe}$ steel samples consists of a ferrite structure, with dispersed inclusions in the form of nitride particles.

According to literary data [8-10], atomic nitrogen diffuses into the $\alpha$-phase of the material, saturating it to the solubility limit, further saturation leads to the formation of $\varepsilon$-phase $(\varepsilon$-phase is a ferrous solution based on iron nitride $\mathrm{Fe}_{3} \mathrm{~N}$, having a hexagonal lattice) composition, i.e. phase nitride or carbonitride structure. As can be seen from Figure 2, the nitriding of $0.3 \mathrm{Cr}-1 \mathrm{Mn}-1 \mathrm{Si}-\mathrm{Fe}$ steel in the electrolyte plasma resulted in significant changes in the structure of the matrix of steel.

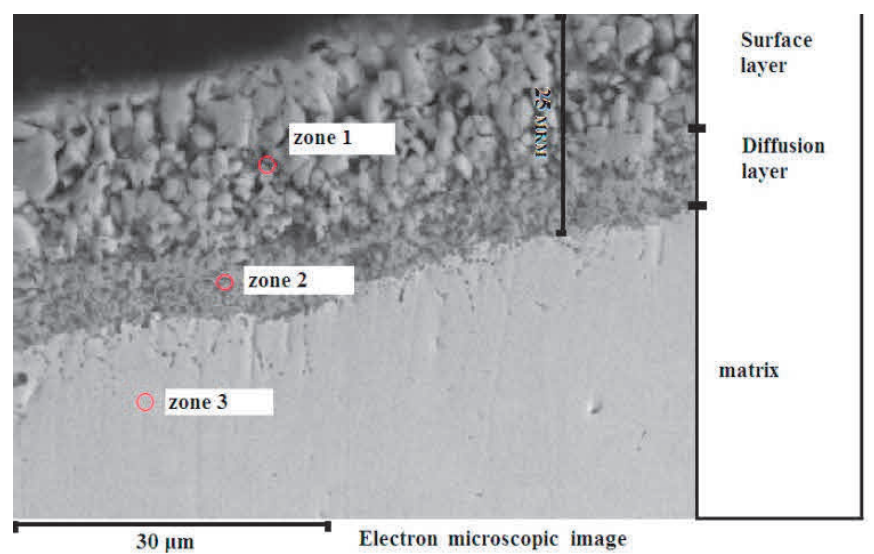

Figure 2 Electronic image of the cross-section of steel $0.3 \mathrm{Cr}-1 \mathrm{Mn}-1 \mathrm{Si}-\mathrm{Fe}$ after plasma electrolytic nitriding on Mode 2

Under the plasma electrolytic nitration, the working electrolyte consists of soda ash $\left(\mathrm{Na}_{2} \mathrm{CO}_{3}\right)$, urea $\left(\left(\mathrm{NH}_{2}\right)_{2} \mathrm{CO}\right)$, ammonium chloride $\left(\mathrm{NH}_{4} \mathrm{Cl}\right)$ of different concentrations, according to the established nitriding regime, there is no glycerol as an oxidizing component that leads to the intensification of iron oxides on the modified surface. 
Figure 3 shows the diffractogram of steel $0.3 \mathrm{Cr}-1 \mathrm{Mn}-1 \mathrm{Si}$-Fe in the delivery condition (Figure 3 (a)) and after electrolytic-plasma nitriding in Mode 2 at a temperature of $750{ }^{\circ} \mathrm{C}$ with duration of 7 minutes (Figure 3 (b)).

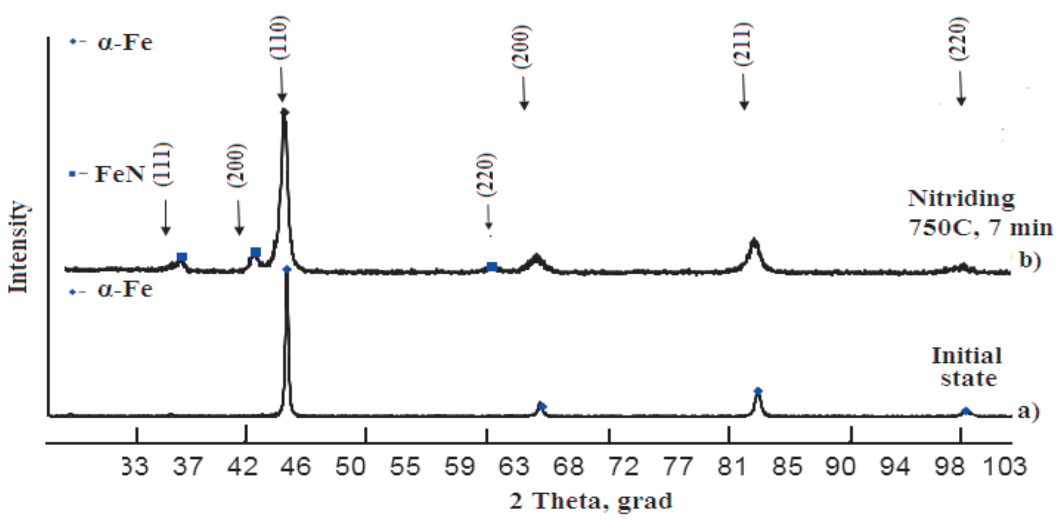

Figure $3 \mathrm{X}$-ray diffraction pattern of the surface of steel $0.3 \mathrm{Cr}-1 \mathrm{Mn}-1 \mathrm{Si}-\mathrm{Fe}$ after electrolytic-plasma nitriding

The conducted researches of X-ray structural analysis showed that the microstructure of a surface of samples of steel $0.3 \mathrm{Cr}-1 \mathrm{Mn}-1 \mathrm{Si}-\mathrm{Fe}$ consists of a-phase and iron nitride $(\mathrm{FeN})$ according to Table 2. However, particles of the $\mathrm{Y}$-phase, and also nitrides of chromium are not detected by $\mathrm{X}$-ray diffraction, possibly because of their dispersion and small amount.

Table 2 The results of the study of the phase composition and structural parameters of steel samples $0.3 \mathrm{Cr}-1 \mathrm{Mn}-1 \mathrm{Si}-\mathrm{Fe}$

\begin{tabular}{|c|c|c|c|c|c|}
\hline Sample & $\begin{array}{c}\text { Discovered } \\
\text { phase }\end{array}$ & Phase content, \% & $\begin{array}{c}\text { Lattice parameter, } \\
\AA\end{array}$ & $\begin{array}{c}\text { OCD sizes, } \\
\text { HM }\end{array}$ & $\begin{array}{c}\Delta \mathrm{d} / \mathrm{d}^{*} 10^{-} \\
3\end{array}$ \\
\hline In delivery condition & $\alpha-F e$ & $>98$ & 2.872 & 43.91 & 0.08 \\
\hline $\begin{array}{c}\text { Plasma electrolytic- nitriding } \\
\text { Mode 2, }\end{array}$ & $\alpha-F e$ & 80.1 & 2.877 & 19.02 & 3.95 \\
\cline { 2 - 6 } 7 min at $\mathrm{t}=750^{\circ} \mathrm{C}$ & FeN cubic & 19.9 & 3.600 & 14.53 & 0.29 \\
\hline
\end{tabular}

The microhardness value of the modified surface layers of steel $0.3 \mathrm{Cr}-1 \mathrm{Mn}-1 \mathrm{Si}-\mathrm{Fe}$ after nitriding in the electrolyte plasma is $\mathrm{H}_{\mu}=7.6$ [GPa] (Figure 4). The hardening of the modified surface layer is caused, apparently, by the fact that it consists of ferrite grains and disperse nitrides of a-phase.

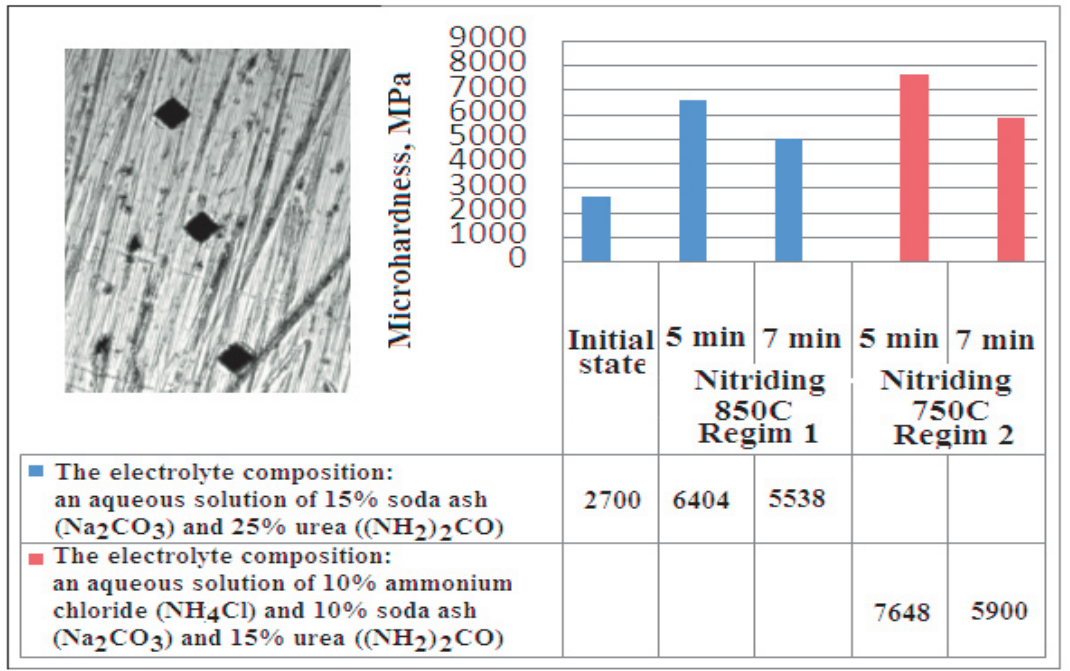

Figure 4 Microhardness of the surface of steel $0.3 \mathrm{Cr}-1 \mathrm{Mn}-1 \mathrm{Si}-\mathrm{Fe}$ before and after nitriding 
Figure 5 shows the experimental work data, the dependences of the wear rate $\left.\left(\mathrm{mm}^{2} / \mathrm{N}\right) / \mathrm{mm}\right)$. There are built the friction coefficient from time and section of the path of $0.3 \mathrm{Cr}-1 \mathrm{Mn}-1 \mathrm{Si}-\mathrm{Fe}$ steel samples before and after modifying the electrolyte in the plasma. The value of the wear rate of the sample steel $0.3 \mathrm{Cr}-1 \mathrm{Mn}-1 \mathrm{Si}-\mathrm{Fe}$ in the delivery condition $7.1 \mathrm{E}-005\left(\left(\mathrm{~mm}^{2} / \mathrm{N}\right) / \mathrm{mm}\right)$, and after nitriding at a temperature of $750{ }^{\circ} \mathrm{C}$ with a duration of 7 minutes is $1.64 \mathrm{E}-005\left(\left(\mathrm{~mm}^{2} / \mathrm{N}\right) / \mathrm{mm}\right)$. Thus, the intensity of wear after nitriding decreases by 4.3 times in comparison by a sample in a condition of delivery.
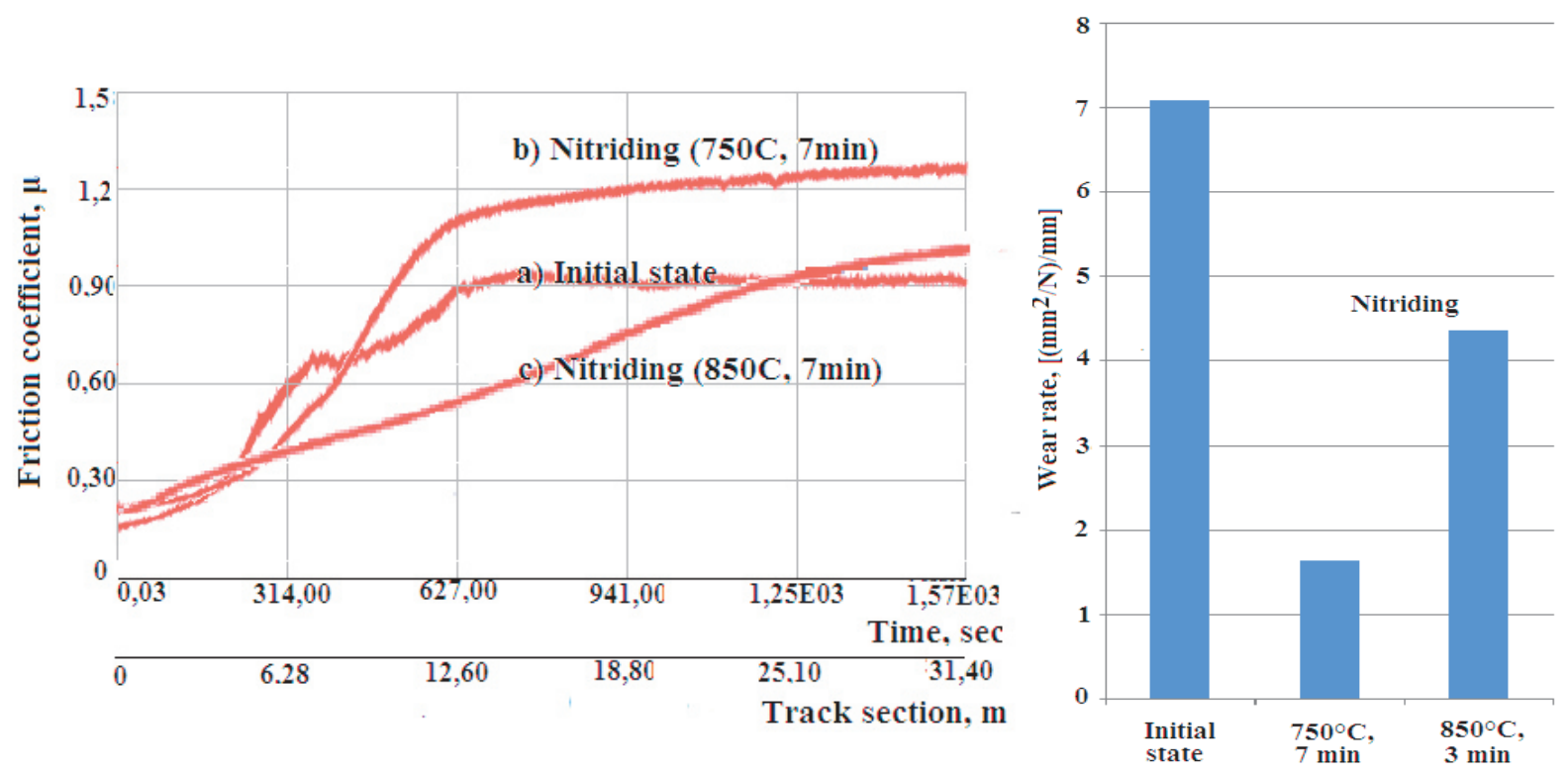

Figure 5 Friction coefficient and wear rate of steel samples $0.3 \mathrm{Cr}-1 \mathrm{Mn}-1 \mathrm{Si}-\mathrm{Fe}$ before and after nitriding

\section{CONCLUSION}

Thus, we can make the following conclusions according to the result of the research of the obtained data. There are:

- established that the microstructure of steel samples $0.3 \mathrm{Cr}-1 \mathrm{Mn}-1 \mathrm{Si}-\mathrm{Fe}$ at different modes of nitriding, consists of $\alpha$-phase and iron nitride ( $\mathrm{FeN})$;

- determined the microhardness values of the modified surface layers of steel $0.3 \mathrm{Cr}-1 \mathrm{Mn}-1 \mathrm{Si}-\mathrm{Fe}$ in the delivery condition $\mathrm{H}_{\mu}=2.7\left[\mathrm{GPa}\right.$ ], and after nitriding in the electrolyte plasma is $\mathrm{H}_{\mu}=2,7$ [GPa];

- obtained the values of the friction coefficient, the wear rate of samples of steel $0.3 \mathrm{Cr}-1 \mathrm{Mn}-1 \mathrm{Si}-\mathrm{Fe}$ in the state of delivery and after nitriding in the plasma of the electrolyte. It has been established that the wear rate after nitriding decreases by 4.3 .

\section{REFERENCES}

[1] BELKIN P.N. Electrochemical heat treatment of metals and alloys. M.: Mir, 2005. p. 336.

[2] NISS V.S., KOSOBUTSKY A.A., ALEKSEEV Yu.G., PARSHUTO A.E., KOROLEV A.Yu. The device for vaporliquid aerosols deposition and purification for resource-saving and environmentally safe electrolytic-plasma treatment. Resource and energy saving technologies and equipment, environmentally friendly technologies: Materials of the International Scientific and Technical Conference, Minsk: BSTU, 2010. Part 2. pp. 218-221.

[3] MELETIS E.I., NIE X., WANG F.L. Electrolytic Plasma Treatment Surface and Coatings Technology 150 (2002), pp. 246-256.

[4] SUMINOV E.I., BELKIN P.N., EPELFELD A.V., LYUDIN V.B., CRIT B.L., BORISOV A.M. Plasma Electrolytic Modification of the Surface of Metals and Alloys. Moscow: Tekhnosfer, 2011. p. 464. 
[5] SOSNIN N.A., ERMAKOV S.A., TOPOLYANSKY P.A. Plasma technology. Welding, coating, hardening: M. Mechanical Engineering. 2008. p. 406.

[6] SKAKOV M.K., ZHUREROVA L.G. Innovative patent of the Republic of Kazakhstan \#27501 for the invention "Way of electrolyte-plasma hardening of details and the device for realization" at 15.05.2013 bulletin \#7.

[7] Patent for useful model of the Republic of Kazakhstan: MPK8 C25F 7/00 / Electrolytic-plasma treatment unit / Skakov M.K, Verigin A.A., Fursov A.V., Parunin S.V., Sapataev E.E., Kurbanbekov S.R. Publ. 11/15/12, Bull. No. 11.

[8] LAKHTIN Yu.M. Gas nitriding of machine parts and tools / Yu.M. Lakhtin, Ya.D. Kogan. - M .: Mashinostroenie, 1982. p. 60.

[9] CHATTERJEE-FISHER R. et al. Nitriding and carbonitriding. / Trans. Of German. / ed. A.V. Soup. - M .: Metallurgy, 1990. p. 280.

[10] KOZLOV E.V., POPOVA N.A., KLIMASHIN S.I. et al. Influence of quenching on the structure and phase composition of cast structural steel 30XH3MFA // Polzunovsky Vestnik. 2005. №2. pp. 153-158. 